\title{
LITERATURE IN LANGUAGE TEACHING
}

\section{Mundi Rahayu}

Jurusan Bahasa dan Sastra Inggris, Fakultas Humaniora dan Budaya, Universitas Islam Negeri Maulana Malik Ibrahim (UIN) Malang

Email. mundi_rahayu@yahoo.com

\begin{abstract}
The role of literature in the ELT classroom has been re-assessed by many experts, and now many of them view literary texts as providing rich linguistic input, in addition to effective stimuli for students to express themselves in other languages. In this way, literature can be a potential source of learner motivation. Literary texts offer a rich source of linguistic input and can help learners to practice the four language skills -speaking, listening, reading and writing- in addition to exemplifying grammatical structures and presenting new vocabulary. It is found out as well that literary texts provide opportunities for multi-sensorial classroom experiences and can appeal to learners with different learning styles.
\end{abstract}

\section{Keywords}

Literature, English Language Teaching, Short Stories

\section{Introduction}

Literature has not only many functions, but power. Many experts identify this power, for instance what is said by Kelly (1996:8) that some of the major values of (children) literature are enjoyment, aesthetics, understanding, imagination, information and knowledge, cognition, and language. In short this idea can be explained as follows. It is the fact that good books give readers pleasure, enjoyment when reading them. Aesthetics pertain to the beauty that the readers perceive in a literary work. Literature is a verbal art that leads readers to appreciate the beauty of language. It adds aesthetic dimensions to readers' lives, leading them to view their personal experiences in different ways. Fictions, nonfiction and poetry are artistic interpretations of experiences, events and people.

Literature also has the value of enhancing understanding self and others. By reading literature readers will perceive themselves by reflecting others experience through the book. Also, understanding cultures lead readers learn about the ties that unite people everywhere. people who come to understand and appreciate various cultures are more likely to realize that people throughout the world share the same emotions, experiences, and problems.

Literary work also functions for developing imagination. Imagination is a creative, constructive, power. Every aspect of daily life involves imagination. People imagine as they talk and interact with others, make choice and decisions, analyze news reports, or assess advertising and entertainment (Sloan in Kelly 1996). Creative thought and imagination are intimately related to higher-order thinking skills. Literature is essential to educating the imagination as it illustrates the unlimited range of the human imagination and extends readers' personal visions of possibilities 
Literature nourishes readers' creative process by stirring and stretching the imagination, providing new information ideas, and perspectives so that readers can imagine the possibilities and elaborate on original ideas. In this way, it expands readers; ability to express imagination in words and images.

Literature also increases information and knowledge. Reading enables them to participate in experiences that go far beyond mere facts. Fine nonfiction writers not only increase their readers; store of knowledge, they also stimulate readers to think about the many dimensions of the concepts explored in their books, encouraging questioning and critical thinking. In this way, literature also stimulates cognition. Literature is a way of thinking it serves as a source of knowledge and a sounding board for children reasoning. All lit stimulates thinking by giving readers substance for reflection, this facilitates cognitive development (Kelly, 1996: 10)

In language teaching, literature provides language model. Language and thinking are so closely interrelated that the ability to think for one's self depends on one's mastery of the language (Kelly, 1996:11). Literature, however, often furnishes a richer model for language than conversation as author frequently use elaborate sentences and sumptuous words, while speakers tend t o employ the same few words over and over in conversation. Teachers, parents, and librarians often hear children use language acquired from their favorite stories.

This paper aims to explain the use of literary work in English language teaching. The literary work that will be analyzed should be interesting, and has valuable things or values to be understood. The work analyzed in this paper, a short story Button, Button by Richard Matheson will be purposed to be applied in English language teaching by exploring its linguistics inputs and its application for practicing language skills. This story tells about the problem of a couple in New York city. They are offered a "package" with some instruction and if it is successfully followed, it will give some amount of money for the doer. The female character is interested in doing this business. Is she successful in getting the amount of money? Unfortunately, it ends in tragic. This is the intriguing problem that leads the readers of this story interested in analyzing and getting valuable lesson.

\section{Method}

The 'Text and Activities' method is the most common approach to using fiction and poetry in the classroom. This method is a kind of low technology one, so that it is easy to be applied in classroom. All we really need are words of a literary text on a page to discussed and analyzed.

In this paper the literary text is used for explaining and understanding, as well as stimulating readers for practicing the language skills. In this case, the literary text as the object of analysis is the short story Button, Button by Richard Matheson, one of the short stories compiled in American Short Stories for the EFL Classroom (1985). This text will be analyzed for its use in the ELT Classroom. The analysis will be emphasized on the linguistic inputs that readers/students can get, such as the grammar structure and vocabularies and the use of the literary work for practicing 4 (four) language skills. This way of analysis can be applied for other literary works, though it is not necessary to apply all of the four language skills at the same work, for instance.

\section{Analysis}

In using the literary text in EFL classroom, the most important thing is to prepare the students to read the text. The preparation is important in giving the students the background for the reading 
to take place. The preparation also should help motivate the students to want to read, so that there will be no students' complaint on the task. This activity should cover up the ideas of literary function or power that are mentioned above. The pre-reading activities should cover the functions of literary works such as enjoyment, aesthetics, understanding, imagination, information and knowledge, cognition, and language.

The pre-reading activities that can be given by teacher to lead for the enjoyment, understanding, imagination, among other are the explanation about the cultural setting of the short story, and some questions related to the cultural setting. The setting of this short story (Button, Button) is New York, a metropolitan city. This setting is easily found out at the beginning of the story, "The package was lying by the front door - a cube-shaped cartoon sealed with tape, their name and address printed by hand: "Mr. and Mrs. Arthur Lewis, 217 E. Thirty-seventh Street, New York, New York 10016." By explaining the cultural setting of the big city, reader will get the ideas on the context, especially the cultural context of the story. For example, the culture of sales marketing does his job in a big city, will give vivid ideas on what and how they are doing and for what purpose. This explanation to the students as the pre-reading activities will lead them to understand the problem faced by the people in such a big city life cultural context. The problem of human being expressed by people through literary works is always interesting because it reflects human's problems and their response towards the problem. Moreover, the problem, often, is universal, meaning that it can happen anywhere and to any people. This understanding will help readers/students perceive the importance of reading and studying literary works to enrich their perspective of life.

The post reading activities that can be delivered to the students are some questions they have to answer at the end of the reading. Such questions are : What does the title Button, Button mean ?, Does the story have tragic end ? Do you agree with the female character, Norma's assertion that the death of someone you have "..never seen..never will see " is not important to you? What is the message the author want to deliver in this story? Does the author have specific idea on the nature of human being expressed in this story?

The questions given identify the comprehension of the readers/students on the story. The comprehension can be seen from the answers to the questions and the discussion further on the answers of the questions. This is also important to identify the students' response and expression on the problems presented in the story. The students' ideas on such problems need to be explore further in group discussion in the classroom.

The linguistics inputs that can be drawn from the stories can be described in two parts, the vocabularies and grammatical structure. The vocabularies that can be learned from this story, for examples, are as follow: vocabularies related to the "sales" and behavior of the characters as well as the condition of people in such cultural context: sales pitch, watchamachallit, monetarily, gadget, genuine offer, shudder, dismay, scope, stack, abruptly, slipper, authentic, incredulous, numb, repress, eccentric, authentic, contemptuous, ridiculous. Teachers need to know exactly the meaning of the words and asks students to find out the meaning and idea of the words. This activity can be followed up with the making of sentences using this word. The students can create their own sentences, by inserting this word in each sentence. This encourages the understanding of the meaning and language producing skill.

The other grammatical structure and vocabularies that are valuable to be learned are some phrases. There are some phrases that are important as the linguistic inputs valuable to observe, 
such as "It is a sick one. Now you are loading things. Not that I believe a word. His voice was guarded. She cut him off. " ...turned over the supper steaks. "The teacher can ask students to find out the meaning of the phrases in the context, and get the whole understanding of the story. This will enrich the students' vocabularies and grammatical structure, as well as the understanding on the plot of the story.

The next function of literary works in English language teaching is its use for practicing the four language skills, though it is not necessary to apply for all of the four language skills at once. Here are some examples of instruction. In writing skill, for example, students are asked to write down the one of the mentioned or discussed expression as the prompt to write down a short paragraph. For example, the expression of "It is a sick one". In this sentence, one refers to the joke. The meaning of the sentence is if it is a joke it is a sick joke, a joke that is not amusing but sickening. Students can continue with the their own ideas from this prompt, to express "the sick one". Such expression can be applied for practicing speaking skill as well. The other examples can be drawn from the other phrases found out in the story. By identifying the phrases, understanding the meaning, and producing it in the students' own expression, the creative reading can be reproduce into other activities covered in other language skills, such as speaking and writing.

\section{Conclusion}

In this paper the literary text is used for explaining and understanding, as well as stimulating readers for practicing the language skills. The short story Button, Button by Richard Matheson here is one of the examples. Readers interested in using literary works can find out other examples and apply it in ELT. The analysis on the linguistic inputs such as grammar structure and vocabularies and the use of the literary work for practicing 4 (four) language skills do not necessary to put away the students' understanding on the human problems presented in the literary works. The language inputs and the students' perceiving on the human problems as well as the enjoyment the aesthetics can be explored at the same time at the classroom to enrich students' appreciation on literary works and all at once improving their language competence. This needs the teacher's creativity in using exploring the literary works as a text to be used in language teaching.

\section{REFERENCE}

Kelly, A. Colette (ed). 1996. Children's Literature: Discovery for aLlifetime. Arizona: Gorsuch Scarisbrick Publisher.

Stanford, A. Stanford (ed). 2006. Responding to Literature $5^{\text {th }}$ ed. New York: Mc Grawhill International Edition.

Queen, David (ed). 1985. Configurations: American Short Stories for the EFL Classroom. English Language Program Division, United States Information Agency, Washington DC.

Matheson, Richard, Button, Button, in David Queen (ed)1985. Configurations: American Short Stories for the EFL Classroom. English Language Program Division, United States Information Agency, Washington DC. 